\title{
Evaluation of different levels of nitrogen, zinc and their combined effect on yield and yield contributing traits of wheat
}

\author{
A Das ${ }^{1 *}$, MAR Sarkar ${ }^{2}$, N Islam ${ }^{2}$ \\ ${ }^{1}$ Gafargaon Islamia Government High School, Gafargaon, Mymensingh, Bangladesh; ${ }^{2}$ Department of Agronomy, \\ Bangladesh Agricultural University, Mymensingh 2202, Bangladesh.
}

\begin{abstract}
Nitrogen and zinc are essentially required for the growth of wheat and the insufficient amount or inappropriate combination of both may severely reduce the yield. The present investigation was carried out at the Agronomy Field Laboratory of Bangladesh Agricultural University, Mymensingh, Bangladesh to evaluate the effect of different levels of nitrogen i.e. $0 \mathrm{~kg} / \mathrm{ha}$ (control), 60,120 and $160 \mathrm{~kg} / \mathrm{ha}$ and zinc i.e. $0 \mathrm{~kg} / \mathrm{ha}$ (control), 1 and $2 \mathrm{~kg} / \mathrm{ha}$ and the interactions of nitrogen and zinc on yield and yield contributing traits of Triticum aestivumL. cv. 'Prodip'. The results showed that there were significant differences in yield and yield contributing traits due to the application of $\mathrm{N}$ and $\mathrm{Zn}$ fertilizers, although some of the yield attributes were non-significant. The maximum plant height (87.67 $\mathrm{cm})$, number of effective tillers plant ${ }^{-1}$ (3.56), grain yield $\left(5.81\right.$ tha $\left.^{-1}\right)$ and straw yield $\left(7.07\right.$ tha $\left.^{-1}\right)$ were obtained from the application of $160 \mathrm{~kg} \mathrm{~N} / \mathrm{ha}$ than at 0/80/120 kg N/ha. Application of $2 \mathrm{~kg} \mathrm{Zn/ha} \mathrm{produced} \mathrm{the} \mathrm{highest} \mathrm{plant}$ height $(81.25 \mathrm{~cm})$, number of effective tillers plant ${ }^{-1}(3.00)$, grain yield $\left(5.22 \mathrm{tha}^{-1}\right)$ and straw yield $\left(6.27 \mathrm{tha}^{-1}\right)$ whereas, the minimum plant height $(80.08 \mathrm{~cm})$, number of effective tillers plant ${ }^{-1}(2.58)$, grain $\left(4.65\right.$ tha $\left.^{-1}\right)$ and straw $\left(5.68\right.$ tha $^{-1}$ ) yield were found in the control. Interaction effect of $\mathrm{N}$ and $\mathrm{Zn}$ on yield and most of the yield attributes were found significant. The maximum number of effective tillers plant ${ }^{-1}(4.00)$, grain $\left(6.27\right.$ tha $\left.^{-1}\right)$ and straw ( 7.40 tha $^{-}$ ${ }^{1}$ ) yield were exhibited from the treatment combination of $160 \mathrm{~kg} \mathrm{~N} \mathrm{ha}^{-1}+2 \mathrm{~kg} \mathrm{Zn} \mathrm{ha}^{-1}$. Grain yield was found to be significantly and positively correlated with number of effective tillers plant ${ }^{-1}$, number of fertile spikelets spike ${ }^{-1}$, number of gains spike ${ }^{-1}$ and straw yield. Therefore, appropriate doses and combinations of nitrogen and zinc would improve the yield of wheat and would provide a rational for the selection of important yield contributing traits for future breeding of wheat for improved yield.
\end{abstract}

Key words: Wheat, nitrogen, zinc, yield traits, correlation

Progressive Agriculturists. All rights reserved

*Corresponding Author: amitbau007@yahoo.com

\section{Introduction}

Wheat is considered as one of the most important and the most consumed cereal crops in world in respect of cultivated area and total production (Faizy et al., 2017). After rice wheat is the second most cultivated cereal in Bangladesh with the production of $3.5 \mathrm{t} / \mathrm{ha}$ comprising of 0.44 million ha of cultivable land (BBS, 2017). It has increased to some extent compared to earlier average yield of $2.78 \mathrm{t} / \mathrm{ha}$ (BBS, 2002)but is still not satisfactory rather it is low compared to that of the leading wheat growing countries of world where the average yield is $7.8 \mathrm{t} / \mathrm{ha}$ (Defra, 2019). The cultivable land of Bangladesh is reducing with time due to the increased population, natural calamities and different biotic and abiotic stresses including soil salinity, 
drought and flood (Gregorio et al., 2002). Therefore, it is very crucial to increase the production of wheat in Bangladesh by increasing its yield as the country needs to feed the increasing population which is evidently, the most challenging problem the nation has been facing these days. And the efficient fertilizer management is very important factor to enhance the yield potential of any crop including wheat and at least 30 to $50 \%$ increased yield is attributable to commercial fertilizers (Firdous et al., 2018; Adnan et al., 2016).

Nitrogen $(\mathrm{N})$ plays noticeable role in plant metabolism and all the vital physiological and metabolic processes in plant are associated with protein of which nitrogen is an essential constituent (Adnan et al., 2016). Nitrogen is the key nutrient element and plays an inevitable role to increase the tillering capacity which leads to higher yield potential. Optimum supply of nitrogen raises the nutritive value, protein content and improves the baking quality of wheat (Ames et al., 2003; Mandic et al., 2015).Application of nitrogen has considered as a primary means of increasing wheat grain yield as well as improves $\mathrm{N}$ uptake and $\mathrm{N}$ use efficiency and consequently nitrogen harvest index (Belete et al., 2018).

Zinc ( $\mathrm{Zn})$ is an important metal component which is the functional, structural and regulatory cofactor of a large number of enzymes (Cakmak, 2008) and essential micronutrient which deficiency is common in wheat growing areas of Bangladesh, particularly in calcareous areas with high soil pH (Majd et al., 2015).Zinc deficiency severely reduces wheat production and nutritional quality of grains (Firdous et al., 2018).The functional role of $\mathrm{Zn}$ includes auxins metabolism, nitrogen metabolism and protection of cells against oxidative stress. Plants emerged from seeds with low $\mathrm{Zn}$ could be highly sensitive to biotic and abiotic stresses. On the contrary, zinc enriched seeds can perform better with respect to seed germination, seedling health, crop growth and finally yield advantage (Quddus et al., 2014).Zinc reduces the carbohydrate content in leaves and stem during the formation of spike and facilitates the assimilation of carbohydrates into the grain. Moreover, zinc causes the better transfer of protein to the wheat grain and improves the grain quality (Majd et al., 2015).

Appropriate combination of macro and micronutrients is often feasible for the higher crop yield. The uptake of zinc from soil to roots, mobilization to edible part and accumulation to sink is supported by nitrogenous proteins (Wang et al., 2016). Nitrogen and Zinc supplementations in wheat have prominent role in sustainable wheat production. Nitrogen is involved in the production of natural chelating agents such asnicotianamine and deoxymugeinic acid which control the translocation of zinc from flag leaves to grain via membrane transport and stimulate the root development (Barunawati et al., 2013; Nie et al., 2017). However, the combined effect nitrogen and zinc or their availability in soil to increase the absorption of zinc especially through the root system of plants are starting to be understood but still far from complete. Therefore, the present study was executed to evaluate the effect of nitrogen and zinc and nitrogen-zinc interaction to improve plant growth and grain yield in wheat.

\section{Materials and Methods}

The experiment was conducted at the Agronomy Field Laboratory of Bangladesh Agricultural University, Mymensingh, Bangladesh. The experimental site lies at $24.75^{\circ} \mathrm{N}$ latitude and $90.50^{\circ} \mathrm{E}$ longitude. The elevation of the experimental area is $18 \mathrm{~m}$ above the sea level. The experimental land belongs to the 'Old Brahmaputra Floodplain' under Agro Ecological Zone-09 (UNDP and FAO, 1988).The soil of the experimental land belongs to the 'Sonatola' series under the general soil type, non-calcareous dark grey floodplain soils. The physical and chemical characteristics of the soil are presented in Table 1.

Plant materials: Theheat tolerant wheat (Triticum aestivum L.) variety 'Prodip' was used as plant 
material. The seeds of 'Prodip' were collected from Bangladesh Institute of Nuclear Agriculture (BINA), Mymensingh, Bangladesh.

Nitrogen and zinc fertilizers: Five doses of nitrogen fertilizer viz. $0 \mathrm{~kg} / \mathrm{ha}$ (control) $\left(\mathrm{N}_{0}\right), 80 \mathrm{~kg} / \mathrm{ha}\left(\mathrm{N}_{1}\right), 120$ $\mathrm{kg} / \mathrm{ha}\left(\mathrm{N}_{2}\right)$ and $160 \mathrm{~kg} / \mathrm{ha}\left(\mathrm{N}_{3}\right)$ and three doses of zinc viz.0 $\mathrm{kg} / \mathrm{ha}$ (control) $\left(\mathrm{Zn}_{0}\right), 1 \mathrm{~kg} / \mathrm{ha}\left(\mathrm{Zn}_{1}\right)$ and $2 \mathrm{~kg} / \mathrm{ha}$ $\left(\mathrm{Zn}_{2}\right)$ were used for growing the seeds of wheat variety 'Prodip'.

Table 1. Physical and chemical characteristics of the experimental site.

\begin{tabular}{ll}
\hline Physical & 0-20 cm depth \\
\hline Textural class & Silty loam \\
Sand (\%) & 15.46 \\
Silt $(0 / 0)$ & 57.72 \\
Clay (\%) & 24.85 \\
Moisture (\%) & 4.08 \\
Field capacity (\%) & 27.90 \\
Water holding capacity (\%) & 57.2 \\
Bulk density $\left(\mathrm{g} / \mathrm{cm}^{3}\right)$ & 1.47 \\
Partial density $\left(\mathrm{g} / \mathrm{cm}^{3}\right)$ & 2.71 \\
Porosity $(\%)$ & 45.76 \\
Hydraulic conductivity $(\mathrm{cm} / \mathrm{hr})$ & 0.68 \\
& $($ moderately \\
& $10 \mathrm{w})$ \\
\hline Chemical & $\mathbf{0 - 2 0}$ cm depth \\
\hline pH & 6.8 \\
Cation exchange capacity & 8.4 \\
Total nitrogen $(\%)$ & 0.11 \\
Organic carbon & 0.68 \\
Available phosphorus (ppm) & 16.72 \\
\hline
\end{tabular}

Experimental design and land preparation: The experiment was laid out in a randomized complete block design with three replications. Each block was divided into 12 unit plots where 12 treatments were allotted randomly. Thus, there were $36(12 \times 3)$ unit plots of $10 \mathrm{~m} \times 10 \mathrm{~m}$. Inter block and inter plot spacing were $1 \mathrm{~m}$ and $0.5 \mathrm{~m}$, respectively. The experimental field was ploughed with a tractor drawn disc plough 20 days before seed sowing. It was further ploughed four times with country plough followed by laddering for breaking clods and leveling the land. All weeds, stubble and crop residues were removed from the experimental field. The land was fertilized with recommended doses of $150 \mathrm{~kg} / \mathrm{ha} \mathrm{TSP}, 100 \mathrm{~kg} / \mathrm{haMOP}$ and $110 \mathrm{~kg} / \mathrm{ha}$ Gypsum. Nitrogen and zinc were applied as per experimental specification. The total amount of TSP, MOP, gypsum, sulphuric acid and one third of the urea were applied at the time of final land preparation prior to seed sowing. The remaining twothirds of urea were top-dressed in two equal splits after 20 and 55 days of seed sowing. Seeds were sown at the rate of $120 \mathrm{~kg} / \mathrm{ha}$ in $25 \mathrm{~cm}$ apart rows. Weeding was performed two times on 18 and 50 days after sowing. The field was irrigated after first weeding and then on 55 days after sowing.

Harvesting and data recording: The crop was harvested at full maturity after four months of planting. The grains and straw were dried in sun for four days and the grains were threshed and cleaned. For data collection 10 plants were selected at random and uprooted from each plot prior to harvesting. The grain and straw yields were recorded plot-wise on $14 \%$ moisture basis and were converted to $t / h a$. The data on plant height, number of total tillers plant ${ }^{-1}$, number of effective tillers plant ${ }^{-1}$, spike length, number of fertile spikeletsspike $^{-1,}$ number of sterile spikelets spike ${ }^{-1}$, number of grains spike ${ }^{-1}$, weight of 1000 grains, grain yield, straw yield, biological yield and harvest index were recorded.

Statistical analysis: The collected data were analyzed statistically and the mean differences were adjudged by Duncan's Multiple Range Test (Gomez and Gomez, 1984) using a computer based statistical program MSTAT.

\section{Result}

According to the ANOVA table (Table 2) the effect of nitrogen doses on all yield traits under study of wheat cultivar 'Prodip' was significant at $1 \%$ level of significance. Whereas, the effect of zinc was highly significant ( $1 \%$ level) particularly in sink based yield 
traits such as total tiller, effective tiller, grain yield, straw yield and harvest index and was significant at 5\% level of significant for number of fertile spikelets, number of grains spike- ${ }^{1}$ and biological yield and was non-significant for plant height, spike length and number of sterile spikelets. The interaction of N-Zn showed significant effect on all yield contributing traits studied except straw yield (Table 2).

Table 2. Analysis of variance (ANOVA) of the studied yield contributing traits of wheat cv. Prodip.

\begin{tabular}{|c|c|c|c|c|c|c|c|c|c|c|c|c|c|}
\hline $\begin{array}{l}\text { Sources of } \\
\text { variation }\end{array}$ & df & PH (cm) & $\begin{array}{c}\text { TT } \\
\text { (No.) }\end{array}$ & $\begin{array}{c}\text { ET } \\
\text { (No.) }\end{array}$ & $\begin{array}{c}\text { SL } \\
(\mathrm{cm})\end{array}$ & $\begin{array}{c}\text { FS } \\
(\text { No.) }\end{array}$ & $\begin{array}{c}\text { GS } \\
\text { (No.) }\end{array}$ & $\begin{array}{c}\text { SS } \\
\text { (No.) }\end{array}$ & $\begin{array}{c}\text { GY } \\
(\mathbf{t} / \mathbf{h a} \mathbf{a})\end{array}$ & $\underset{(t / h a)}{S Y}$ & $\begin{array}{c}\text { TGW } \\
\text { (g) }\end{array}$ & $\begin{array}{c}\text { BY } \\
(\mathbf{t} / \mathbf{h a})\end{array}$ & HI (\%) \\
\hline Replication & 2 & 1.66 & 0.19 & 0.001 & 0.01 & 0.29 & 1.61 & 0.05 & 0.001 & 0.004 & 0.67 & 0.03 & 2.76 \\
\hline $\mathrm{N}$ level & 3 & $361.73 * *$ & $10.10 * *$ & $3.80^{* *}$ & $5.18 * *$ & $23.95 * *$ & $441.3 * *$ & $0.26 * *$ & $0.05 * *$ & $0.08 * *$ & $89.35 * *$ & $1.33 * *$ & $68.56^{* *}$ \\
\hline Zn level & 2 & $5.44 \mathrm{NS}$ & $1.03 * *$ & $0.58^{* *}$ & $0.03 \mathrm{NS}$ & $0.53 *$ & $2.08 * *$ & $0.02 \mathrm{NS}$ & $0.01^{* *}$ & $0.01 * *$ & $11.51 * *$ & $0.04 *$ & $53.73 * *$ \\
\hline $\begin{array}{l}\mathrm{N} \times \mathrm{Zn} \\
\text { level }\end{array}$ & 6 & $30.48 * *$ & $0.55 * *$ & $0.25^{* *}$ & $0.43 * *$ & $1.34 * *$ & $9.62 * *$ & $0.09 * *$ & $0.02 * *$ & $0.001 \mathrm{NS}$ & $2.83 *$ & $0.08^{* *}$ & $20.97 * *$ \\
\hline Error & 22 & 8.22 & 0.16 & 0.01 & 0.13 & 0.15 & 0.58 & 0.02 & 0.001 & 0.002 & 1.10 & 0.01 & 1.62 \\
\hline
\end{tabular}

$* *=$ Significant at $1 \%$ level of probability, $*=$ Significant at $5 \%$ level of probability, NS $=$ Not significant

Here, $\mathrm{df}=$ degrees of freedom, $\mathrm{PH}=$ plant height $(\mathrm{cm}), \mathrm{TT}=$ number of total tillers plant ${ }^{-1}, \mathrm{ET}=$ number of effective tillers plant ${ }^{-1}, \mathrm{SL}=$ spike length $(\mathrm{cm}), \mathrm{FS}=$ number of fertile spikeletsspike ${ }^{-1}, \mathrm{GS}=$ number of grains spike ${ }^{-1}, \mathrm{SS}=$ number of sterile spikelets spike ${ }^{-1}, \mathrm{GY}=$ grain yield (t/ha), $\mathrm{SY}=$ straw yield ( $\left.\mathrm{t} / \mathrm{ha}\right), \mathrm{TGW}=1000$ grain weight $(\mathrm{g})$, $\mathrm{BY}=$ biological yield (t/ha) and $\mathrm{HI}=$ harvest index $(\%)$.

Effect of different nitrogen levels on yield contributing characters: The results showed that all the yield traitsstudied varied significantly with different $\mathrm{N}$ levels. The tallest plant height $(87.67 \mathrm{~cm})$, maximum number of total tillers plant ${ }^{-1}$ (4.67), maximum number of fertile spikelets spike $^{-1}(19.67)$, maximum number of grains spike $^{-1}$ (47.78) and the longest spike length $(10.67 \mathrm{~cm})$ were obtained when the crop was fertilized with $160 \mathrm{~kg} \mathrm{~N} /$ haand the shortest plant height $(72.33 \mathrm{~cm})$, the lowest number of total tillers plant ${ }^{-1}$ (2.22), minimum number of fertile spikelets spike ${ }^{-1}(16.00)$, the lowest number of grains $\operatorname{spike}^{-1}(31.67)$ and the shortest spike length $(8.89 \mathrm{~cm})$ were observed in control (Table 3). Application of 160 $\mathrm{kg} \mathrm{N} /$ ha provided the highest 1000 -grain weight (51.81 g), grain yield (5.81 t/ha) and straw yield (7.07 t/ha)and the lowest grain weight (44.34 g), grain yield(4.05 t/ha) and straw yield (4.84 t/ha)were recorded from control treatment without $\mathrm{N}$ application. Similarly the highest $\mathrm{N}$ level gave the maximum biological yield (13.40 t/ha) and harvest index (43.42\%) while biological yield $(10.86 \mathrm{t} / \mathrm{ha})$ and harvest index $(37.59 \%)$ were low in control (Table 3).

Effect of different zinc levels on yield contributing characters: Application of zinc (1 or $2 \mathrm{~kg} / \mathrm{ha}$ ) showed significant effect on number of total tiller (3.58), effective tiller (3.0), grain yield (5.22 t/ha), straw yield (6.27 t/ha), 1000-grain weight (49.19 g), harvest index (43.67\%), biological yield (11.98 t/ha), number of fertile spikelets spike ${ }^{-1}(18.17)$ and number of grains spike $^{-1}$ (40.83) than control (Table 3). Number of sterile spikelets spike ${ }^{-1}$ was not influenced significantly due to different levels of zinc. However, the highest number of sterile spikelets spike ${ }^{-1}(5.93)$ was found in control and the lowest (5.71) was obtained from $2 \mathrm{~kg}$ $\mathrm{Zn} \mathrm{ha}{ }^{-1}$. Fertilization with zinc showed non-significant effect on plant height and spike length (Table 3).

Effect of nitrogen $\times$ zinc interactions on yield contributing characters: Crop response to $\mathrm{N}$ and $\mathrm{Zn}$ 
interaction for yield contributing traits in wheat cv. Prodip is presented in Table 4. Results showed that the interaction of $\mathrm{N}$ and $\mathrm{Zn}$ levels had significant effect on plant height and spike length. The highest plant height $(88.00 \mathrm{~cm})$ and spike length $(10.67 \mathrm{~cm})$ were found when the crop was fertilized with $160 \mathrm{~kg} \mathrm{~N} / \mathrm{ha}+1 \mathrm{~kg}$ $\mathrm{Zn} / \mathrm{ha}$ which is statistically similar with other combinations of $\mathrm{N}$ and $\mathrm{Zn}$ than the control without any supplement of $\mathrm{N}-\mathrm{Zn}(71.00 \mathrm{~cm}$ and 8.67 respectively).

Table 3. Effect of nitrogen and zinc on yield and yield contributing characters of wheat cv. Prodip.

\begin{tabular}{|c|c|c|c|c|c|c|c|c|c|c|c|c|}
\hline Treatments & PH (cm) & TT (No.) & ET (No.) & SL (cm) & FS (No.) & GS (No.) & SS (No.) & $\begin{array}{c}\text { GY } \\
\text { (t/ha) }\end{array}$ & SY (t/ha) & TGW (g) & BY (t/ha) & HI (\%) \\
\hline \multicolumn{13}{|c|}{ Nitrogen doses } \\
\hline $\mathrm{N}_{0}(0 \mathrm{~kg} / \mathrm{ha})$ & $72.33 \mathrm{c}$ & $2.22 \mathrm{~d}$ & $2.00 \mathrm{~d}$ & $8.89 \mathrm{~d}$ & $16.00 \mathrm{~d}$ & $31.67 \mathrm{~d}$ & $6.01 \mathrm{ab}$ & $4.05 \mathrm{c}$ & $4.84 \mathrm{~d}$ & $44.34 \mathrm{~d}$ & $10.86 \mathrm{c}$ & $37.59 \mathrm{c}$ \\
\hline $\mathrm{N}_{1}(80 \mathrm{~kg} / \mathrm{ha})$ & $81.56 \mathrm{~b}$ & $2.778 \mathrm{c}$ & $2.556 \mathrm{c}$ & $9.78 \mathrm{c}$ & $17.78 \mathrm{c}$ & $38.33 \mathrm{c}$ & $5.06 \mathrm{c}$ & $4.72 \mathrm{~b}$ & $5.85 \mathrm{c}$ & $47.67 \mathrm{c}$ & $10.90 \mathrm{c}$ & $43.32 \mathrm{a}$ \\
\hline $\mathrm{N}_{2}(120 \mathrm{~kg} / \mathrm{ha})$ & $81.89 \mathrm{~b}$ & $3.556 \mathrm{~b}$ & $2.889 \mathrm{~b}$ & $10.22 \mathrm{~b}$ & $19.11 \mathrm{~b}$ & $43.89 \mathrm{~b}$ & $5.83 \mathrm{~b}$ & $4.96 \mathrm{~b}$ & $6.39 \mathrm{~b}$ & $49.48 \mathrm{~b}$ & $12.22 \mathrm{~b}$ & $40.59 \mathrm{~b}$ \\
\hline $\mathrm{N}_{3}(160 \mathrm{~kg} / \mathrm{ha})$ & $87.67 \mathrm{a}$ & $4.66 \mathrm{a}$ & $3.56 \mathrm{a}$ & $10.67 \mathrm{a}$ & $19.67 \mathrm{a}$ & $47.78 \mathrm{a}$ & $6.32 \mathrm{a}$ & $5.81 \mathrm{a}$ & $7.07 \mathrm{a}$ & $51.81 \mathrm{a}$ & $13.40 \mathrm{a}$ & $43.42 \mathrm{a}$ \\
\hline $\mathrm{LSD}_{0.05}$ & 2.80 & 0.395 & 0.102 & 0.353 & 0.374 & 0.749 & 0.044 & 0.031 & 0.044 & 1.02 & 0.031 & 1.25 \\
\hline Sx & 0.955 & 0.135 & 0.035 & 0.121 & 0.127 & 0.255 & 0.015 & 0.011 & 0.015 & 0.349 & 0.011 & 0.425 \\
\hline $\begin{array}{l}\text { Level of } \\
\text { significance }\end{array}$ & $* *$ & $* *$ & $* *$ & $* *$ & $* *$ & $* *$ & $* *$ & $* *$ & $* *$ & $* *$ & $* *$ & $* *$ \\
\hline \multicolumn{13}{|c|}{ Zinc doses } \\
\hline $\mathrm{Zn}_{0}(0 \mathrm{~kg} / \mathrm{ha})$ & 81.25 & $3.00 \mathrm{~b}$ & $2.58 \mathrm{~b}$ & 9.918 & $18.33 \mathrm{a}$ & $40.00 \mathrm{~b}$ & 5.93 & $4.65 \mathrm{~b}$ & $5.68 \mathrm{~b}$ & $47.26 \mathrm{~b}$ & $11.63 \mathrm{~b}$ & $39.98 \mathrm{~b}$ \\
\hline $\mathrm{Zn}_{1}(1 \mathrm{~kg} / \mathrm{ha})$ & 81.25 & $3.33 \mathrm{ab}$ & $2.667 \mathrm{~b}$ & 9.835 & $17.92 \mathrm{~b}$ & $40.83 \mathrm{a}$ & 5.77 & $4.78 \mathrm{~b}$ & $6.15 \mathrm{a}$ & $48.52 \mathrm{a}$ & $11.92 \mathrm{a}$ & $40.04 \mathrm{~b}$ \\
\hline $\mathrm{Zn}_{2}(2 \mathrm{~kg} / \mathrm{ha})$ & 80.08 & $3.58 \mathrm{a}$ & $3.000 \mathrm{a}$ & 9.917 & $18.17 \mathrm{ab}$ & $40.42 \mathrm{ab}$ & 5.71 & $5.22 \mathrm{a}$ & $6.27 \mathrm{a}$ & $49.19 \mathrm{a}$ & $11.98 \mathrm{a}$ & $43.67 \mathrm{a}$ \\
\hline $\mathrm{LSD}_{0.05}$ & 2.43 & 0.342 & 0.088 & 0.030 & 0.324 & 0.649 & 0.038 & 0.027 & 0.038 & 0.888 & 0.027 & 1.08 \\
\hline Sx & 0.827 & 0.116 & 0.0302 & 0.104 & 0.111 & 0.221 & 0.013 & 0.009 & 0.013 & 0.302 & 0.009 & 0.368 \\
\hline $\begin{array}{l}\text { Level of } \\
\text { significance }\end{array}$ & NS & $* *$ & $* *$ & NS & $*$ & $*$ & NS & $* *$ & $* *$ & $* *$ & $*$ & $* *$ \\
\hline CV\% & 3.55 & 12.26 & 3.84 & 3.66 & 2.11 & 1.90 & 7.84 & 5.32 & 7.94 & 2.17 & 2.90 & 3.10 \\
\hline
\end{tabular}

$* *=$ Significant at $1 \%$ level of probability, $*=$ Significant at $5 \%$ level of probability, NS $=$ Not significant, LSD $=$ Least significant difference, $\mathrm{CV}=$ Coefficient of variation, $\mathrm{Sx}=$ Sample standard deviation.

Here, $\mathrm{df}=$ degrees of freedom, $\mathrm{PH}=$ plant height $(\mathrm{cm}), \mathrm{TT}=$ number of total tillers plant ${ }^{-1}, \mathrm{ET}=$ number of effective tillers plant ${ }^{-1}, \mathrm{SL}=$ spike length $(\mathrm{cm}), \mathrm{FS}=$ number of fertile spikeletsspike ${ }^{-1}$ GS $=$ number of grains spike $^{-1}, \mathrm{SS}=$ number of sterile spikelets spike ${ }^{-1}, \mathrm{GY}=$ grain yield $(\mathrm{t} / \mathrm{ha}), \mathrm{SY}=$ straw yield (t/ha), TGW = 1000 grain weight $(\mathrm{g}), \mathrm{BY}=$ biological yield $(\mathrm{t} / \mathrm{ha})$ and $\mathrm{HI}=$ harvest index $(\%)$.

Number of total tillers (4-5) and effective tillers (3-4) were high in the higher doses of $\mathrm{N}$ combined with $\mathrm{Zn}$ than control (2). Number of fertile spikelets spike ${ }^{-1}$ was maximum (19.33-19.67) with the application of $\mathrm{N}$ and $\mathrm{Zn}$ whereas number of sterile spikelets spike ${ }^{-1}$ was minimum (5.07- 6.3) than the control (17.00 and 6.87 respectively). Moreover, the number of grains spike ${ }^{-1}$ (47.33), grain yield (6.27 t/ha), straw yield (7.40 t/ha), 1000-grain weight (52.72 g), biological yield (14.10 t/ha) and harvest index (44.44\%) were significantly high with the supplement with $160 \mathrm{~kg} \mathrm{~N} / \mathrm{ha}+2 \mathrm{~kg}$ $\mathrm{Zn} / \mathrm{ha}$ than those of in the control (Table 4).

The grain yield of wheat was higher due to the individual application of the highest levels of nitrogen $(160 \mathrm{~kg} / \mathrm{ha})$ and zinc $(2 \mathrm{~kg} / \mathrm{ha})$. Moreover, the combination of the highest levels of both $(\mathrm{N}-\mathrm{Zn})$ showed the utmost gain yield (6.27 t/ha) (Figure 1). 
Table 4. Interaction effect of nitrogen $(\mathrm{N})$ and zinc $(\mathrm{Zn})$ on yield and yield contributing traits of wheat cv. Prodip.

\begin{tabular}{|c|c|c|c|c|c|c|c|c|c|c|c|c|}
\hline $\begin{array}{l}\text { Treatments } \\
\text { N x Z Zn } \\
\text { (kg/ha) }\end{array}$ & PH (cm) & TT (No.) & ET (No.) & SL (cm) & FS (No.) & GS (No.) & SS (No.) & GY (t/ha) & SY (t/ha) & TGW (g) & BY (t/ha) & HI (\%) \\
\hline $\mathrm{N}_{0} \mathrm{Zn}_{0}$ & $71.00 \mathrm{c}$ & $2.00 \mathrm{c}$ & $2.00 \mathrm{e}$ & $8.67 \mathrm{c}$ & $17.00 \mathrm{~d}$ & $31.00 \mathrm{f}$ & $6.87 \mathrm{a}$ & $3.63 \mathrm{f}$ & $4.20 \mathrm{~g}$ & $43.25 \mathrm{~d}$ & $11.10 \mathrm{e}$ & $32.86 \mathrm{c}$ \\
\hline $\mathrm{N}_{1} \mathrm{Zn}_{1}$ & $85.00 \mathrm{a}$ & $3.00 \mathrm{~b}$ & $2.67 \mathrm{~d}$ & $10.00 \mathrm{a}$ & $18.33 \mathrm{~b}$ & $41.00 \mathrm{~d}$ & $5.23 \mathrm{e}$ & $4.63 \mathrm{e}$ & $5.80 \mathrm{f}$ & $47.70 \mathrm{c}$ & $11.10 \mathrm{e}$ & $41.75 \mathrm{~b}$ \\
\hline $\mathrm{N}_{1} \mathrm{Zn}_{2}$ & $79.33 \mathrm{~b}$ & $3.33 \mathrm{~b}$ & $3.00 \mathrm{c}$ & $9.67 \mathrm{ab}$ & $18.00 \mathrm{bc}$ & $37.00 \mathrm{e}$ & $5.07 \mathrm{f}$ & $4.97 \mathrm{~d}$ & $6.08 \mathrm{e}$ & $47.40 \mathrm{c}$ & $11.10 \mathrm{e}$ & $44.70 \mathrm{a}$ \\
\hline $\mathrm{N}_{2} \mathrm{Zn}_{1}$ & $77.33 \mathrm{~b}$ & $3.33 \mathrm{~b}$ & $2.67 \mathrm{~d}$ & $9.67 \mathrm{ab}$ & $18.67 \mathrm{~b}$ & $42.33 \mathrm{c}$ & $5.69 \mathrm{~d}$ & $4.93 \mathrm{~d}$ & $6.40 \mathrm{~d}$ & $50.01 \mathrm{~b}$ & $12.10 \mathrm{~d}$ & $40.68 \mathrm{~b}$ \\
\hline $\mathrm{N}_{2} \mathrm{Zn}_{2}$ & $84.00 \mathrm{a}$ & $4.00 \mathrm{a}$ & $3.00 \mathrm{c}$ & $10.67 \mathrm{a}$ & $19.33 \mathrm{a}$ & $46.00 \mathrm{~b}$ & $6.05 \mathrm{c}$ & $5.20 \mathrm{c}$ & $6.58 \mathrm{c}$ & $50.63 \mathrm{~b}$ & $12.57 \mathrm{c}$ & $41.43 \mathrm{~b}$ \\
\hline $\mathrm{N}_{3} \mathrm{Zn}_{1}$ & $88.00 \mathrm{a}$ & $4.33 \mathrm{a}$ & $3.33 \mathrm{~b}$ & $10.67 \mathrm{a}$ & $19.33 \mathrm{a}$ & $47.33 \mathrm{a}$ & $6.08 \mathrm{c}$ & $5.53 \mathrm{~b}$ & $7.10 \mathrm{~b}$ & $52.62 \mathrm{a}$ & $13.20 \mathrm{~b}$ & $41.96 \mathrm{~b}$ \\
\hline $\mathrm{N}_{3} \mathrm{Zn}_{2}$ & $85.67 \mathrm{a}$ & $5.00 \mathrm{a}$ & $4.00 \mathrm{a}$ & $10.33 \mathrm{a}$ & $19.67 \mathrm{a}$ & $47.33 \mathrm{a}$ & $6.63 \mathrm{~b}$ & $6.27 \mathrm{a}$ & $7.40 \mathrm{a}$ & $52.72 \mathrm{a}$ & $14.10 \mathrm{a}$ & $44.44 \mathrm{a}$ \\
\hline $\mathrm{LSD}_{0.05}$ & 4.85 & 0.685 & 0.177 & 0.612 & 0.649 & 1.29 & 0.076 & 0.054 & 0.076 & 1.778 & 0.054 & 2.16 \\
\hline Sx & 1.65 & 0.233 & 0.060 & 0.209 & 0.221 & 0.442 & 0.026 & 0.018 & 0.026 & 0.605 & 0.018 & 0.737 \\
\hline $\begin{array}{l}\text { Level of } \\
\text { significance }\end{array}$ & $* *$ & $* *$ & $* *$ & $* *$ & $* *$ & $* *$ & $* *$ & $* *$ & $* *$ & $*$ & $* *$ & $* *$ \\
\hline CV\% & 3.55 & 12.26 & 3.84 & 3.66 & 2.11 & 1.90 & 7.84 & 5.32 & 7.94 & 2.17 & 2.90 & 3.10 \\
\hline
\end{tabular}

$* *=$ Significant at $1 \%$ level of probability, $*=$ Significant at $5 \%$ level of probability, NS $=$ Not significant, LSD $=$ Least significant difference, $\mathrm{CV}=$ Coefficient of variation, $\mathrm{Sx}=$ Sample standard deviation

Here, $\mathrm{df}=$ degrees of freedom, $\mathrm{PH}=$ plant height $(\mathrm{cm}), \mathrm{TT}=$ number of total tillers plant ${ }^{-1}, \mathrm{ET}=$ number of effective tillers plant ${ }^{-1}, \mathrm{SL}=$ spike length $(\mathrm{cm}), \mathrm{FS}=$ number of fertile spikeletsspike ${ }^{-1}, \mathrm{GS}=$ number of $_{\text {grains }}$ spike $^{-1}, \mathrm{SS}=$ number of sterile spikelets spike ${ }^{-1}, \mathrm{GY}=$ grain yield (t/ha), $\mathrm{SY}=$ straw yield (t/ha), TGW $=1000$ grain weight $(\mathrm{g})$, $\mathrm{BY}=$ biological yield $(\mathrm{t} / \mathrm{ha})$ and $\mathrm{HI}=$ harvest index $(\%)$.

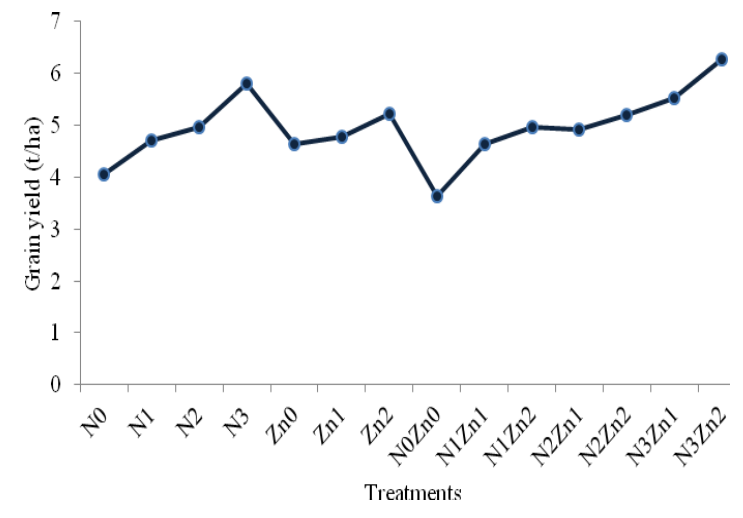

Figure 1. Effect of different nitrogen levels $\left(\mathrm{N}_{0}=0\right.$ $\mathrm{kg} / \mathrm{ha}, \mathrm{N}_{1}=80 \mathrm{~kg} / \mathrm{ha}, \mathrm{N}_{2}=120 \mathrm{~kg} / \mathrm{ha}$ and $\left.\mathrm{N}_{4}=160 \mathrm{~kg} / \mathrm{ha}\right) ;$ zinc levels $\left(\mathrm{Zn}_{0}=0 \mathrm{~kg} / \mathrm{ha}\right.$, $\mathrm{Zn}_{1}=1 \mathrm{~kg} / \mathrm{ha}$ and $\mathrm{Zn}_{2}=2 \mathrm{~kg} / \mathrm{ha}$ ) and their interactions $\mathrm{N}-\mathrm{Zn}$ on the grain yield $(\mathrm{t} / \mathrm{ha})$ of wheat cv. Prodip.
Individual application of Nitrogen or zinc showed intriguing findings on number of fertile and sterile spikelets such as spikelet fertility increased with the high nitrogen levels $(120 / 160 \mathrm{~kg} / \mathrm{ha})$ and there were no significant variations on spikelet fertility or sterility due to zinc application. However, in both cases the number of fertile spikelets was higher than the number of sterile spikelets (Figure 2A).

On the contrary, the combination of both nitrogen and zinc gave maximum fertile spikelets (18 to 20), notably when the high levels of nitrogen (120 or 160 $\mathrm{kg} / \mathrm{ha}$ ) were combined with zinc (1 or $2 \mathrm{~kg} / \mathrm{ha}$ ) (Figure 2B).

The correlation matrix (Table 5) represented that the number of effective tillers plant ${ }^{-1}$, number of grains spike $^{-1}$ and straw yield showed highly significant correlation with grain yield. Moreover, fertile spikelets 
spike $^{-1}$ exhibited significant correlation with grain yield.

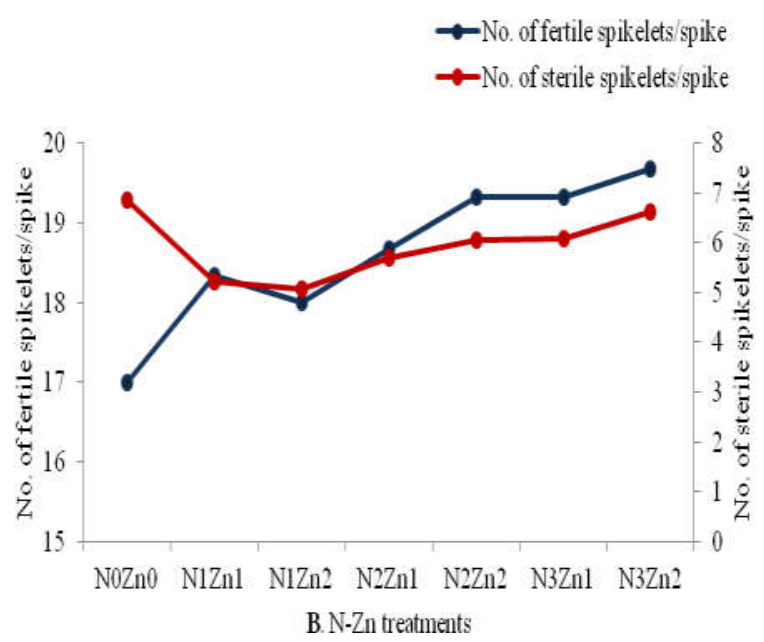

Figure 2. Effect of nitrogen and zinc (A) and their interactions (B) on spikelet fertility and sterility of wheat cv. Prodip $\left(\mathrm{N}_{0}=0 \mathrm{~kg} / \mathrm{ha}, \mathrm{N}_{1}=80 \mathrm{~kg} / \mathrm{ha}, \mathrm{N}_{2}=120 \mathrm{~kg} / \mathrm{ha}, \mathrm{N}_{4}=160 \mathrm{~kg} / \mathrm{ha}\right.$ and $\mathrm{Zn}_{0}=0 \mathrm{~kg} / \mathrm{ha}, \mathrm{Zn} \mathrm{n}_{1}=1 \mathrm{~kg} / \mathrm{ha}$, $\left.\mathrm{Zn}_{2}=2 \mathrm{~kg} / \mathrm{ha}\right)$.

Table 5. Correlation matrix of selected yield contributing traits of wheat cv. Prodip.

\begin{tabular}{lll}
\hline Correlation characters & Correlation coefficient (r) & $\mathbf{R}^{2}$ \\
\hline Grain yield and number of effective tillers plant & -1 & 0.54 \\
Grain yield and number of fertile spikelets spike & $0.734^{* *}$ & 0.47 \\
Grain yield and number of grains spike & $0.687^{*}$ & 0.59 \\
Grain yield and straw yield & $0.771^{* *}$ & 0.93 \\
\hline
\end{tabular}

\section{Discussion}

Higher input levels of $\mathrm{N}$ imparted increased photosynthetic activity, increased number of leaf, vigorous vegetative growth, better assimilation and metabolic rates, therefore resulted in better crop productivity in wheat (Mandic et al., 2015). The present study showed that $160 \mathrm{~kg} / \mathrm{ha} \mathrm{N}$ application resulted significant increase in all yield contributing traits of wheat cv. Prodip. Previous studies showed that the application of $150 \mathrm{~kg} / \mathrm{ha} \mathrm{N}$ resulted in increased plant height, spike length, number of spikelets per spike, weight of grains per spike, 1000 grain weight, grain yield and biological yield (Mandic et al., 2015; Adnan et al., 2016, Belete et al., 2018), which is in accordance with present findings. Research reported that higher grain yield (8.0 $\mathrm{t} / \mathrm{ha}$ ) was gained with the treatment receiving $240 \mathrm{~kg}$ $\mathrm{N} / \mathrm{ha}$ than in control (3.9 kg/ha), $120 \mathrm{~kg} \mathrm{~N} / \mathrm{ha}(4.4$ t/ha), and $360 \mathrm{~kg} \mathrm{~N} / \mathrm{ha} \mathrm{(6.5} \mathrm{t/ha)} \mathrm{(Abedi} \mathrm{et} \mathrm{al.,} \mathrm{2011),}$ while grain yield was $5.81 \mathrm{t} /$ ha due to the supplement of $160 \mathrm{~kg} \mathrm{~N} /$ ha in the present study. The use of large amount of $\mathrm{N}$ increases production costs and reduce the economic benefits. The increase in wheat production is possible by selecting adapted genotypes with improved nitrogen use efficiency (Mandic et al., 2015). It was also reported that increasing $\mathrm{N}$ level resulted in increased grain yield, straw yield, biomass accumulation, 1000- grain weight, number of spike in wheat than that of control, it may be due to the effect of $\mathrm{N}$ which is one of the major macronutrient for the plants of which plant structural and functional proteins are produced (Marino et al., 2009; Faizy et al., 
2017).Earlier findings showed that $\mathrm{N}$ application at the rate of $150 \mathrm{~kg} \mathrm{~N} / \mathrm{ha}$ produced 44.8 grains per spike that was significantly greater than $90 \mathrm{~kg} \mathrm{~N} / \mathrm{ha}$. On the average maximum 1000 grain weight $(37.7 \mathrm{~g})$, grain yield (2.6 /ha) and biological yield (7.8 t/ha) was obtained at $150 \mathrm{~kg} \mathrm{~N} / \mathrm{ha}$ (Adnan et al., 2016). On the other hand our results showed higher estimate of all these traits due to the application of slightly higher level of $\mathrm{N}(160 \mathrm{~kg} / \mathrm{ha})$.

Increase in grain and straw yield is due to the role of $\mathrm{Zn}$ in stimulation and catalysis of various metabolic processes and it is involved in growth and development of plants (Imran et al., 2015). Zinc fertilizer allows the plant to produce more chlorophyll and thus the plant foliage develops and consequently the plant yield increases (Majd et al., 2015). The results represented that zinc has a vital influence in increasing grain yield $(5.22 \mathrm{t} / \mathrm{ha})$ via highest 1000 grain weight (49.19 g) at $2 \mathrm{~kg} \mathrm{Zn/ha,} \mathrm{while} \mathrm{previous}$ research showed similar findings of higher grain yield $(4.1 \mathrm{t} / \mathrm{ha})$ and 1000 -grain weight $(39.90 \mathrm{~g})$ with zinc (3-5 kh/ha) application than control (Majd et al., 2015). Previous results showed that the effect of $\mathrm{Zn}$ application was significant on the grains/spike, fertile spikelets, grain yield and straw yield (Firdous et al., 2018) but had no effect on sterility percentage, spike length and plant height. Maximum reduction in sterility percentage was found in soil along with basal application (Firdous et al., 2018) and foliar application of $\mathrm{Zn}$ (Abbas et al., 2010). Similar findings of nonsignificant effect of zinc application on plant height, spike length and number of sterile spikelets were observed in present study. Therefore, combination of basal and foliar application of zinc would provide a better grain yield is attributable to the improved physiology of plants with the added Zn (Abbas et al., 2010.) Keram et al., (2013) also reported that the straw yield of wheat and harvest index was significantly increased with the application of zinc which was also observed in present study.

Nitrogen is critical for zinc accumulation in wheat grain via enhancing $\mathrm{Zn}$ absorption into plant roots (Liu et al., 2018). However, several researches showed that the lower rate of $\mathrm{Zn}$ was more favorable than higher rate in terms of grain yield. Plant height, straw yield, grain yield was improved with increasing rates of $\mathrm{N}$ (120 or $150 \mathrm{~kg} / \mathrm{ha}$ ) combined with different levels of $\mathrm{Zn}(0,5,10 \mathrm{~kg} / \mathrm{ha})$ than the individual application (Ahmadi et al., 2016; Akram et al., 2017). Maximum emergence, number of tillers, plant height and number of spikes were recorded in plots which were sprayed with $0.5 \% \mathrm{~N}, 0.5 \% \mathrm{~K}$ and $0.5 \% \mathrm{Zn}$ solutions while minimum were recorded in control plots (Gulet al., 2011).There were significant effects of $\mathrm{N}$ application on the spike number, the grain number per spike and grain yield as well as $\mathrm{Zn}$ application showed significant effect on the spike number, thousand kernel weight and grain yield. But the spike number, thousand kernel weights, grain yield and other yield components were significantly increased by $\mathrm{N}$ combined with $\mathrm{Zn}$ application, which produced the highest value (Liu et al., 2018). All these findings are in accordance to the current observations. These results suggested that $\mathrm{N}$ combined with $\mathrm{Zn}$ application was more beneficial to enhance the growth and yield of wheat (Aciksoz et al., 2011) than their individual application. Previous study showed N combined with $\mathrm{Zn}$ application significantly increased $\mathrm{Zn}$ concentration in the shoot and grain of winter wheat that suggested $\mathrm{Zn}$ absorption and transfer from roots to shoots and translocation to grain (Liu et al., 2018). It was also observed that there was a significant positive correlation between $\mathrm{Zn}$ and $\mathrm{N}$ concentration that revealed the enhanced $\mathrm{Zn}$ membrane transport and stimulated root development (Nie et al., 2017; Liu et al., 2018).

The present study showed that the grain yield was highly correlated with number of effective tillers, fertile spikelets, grains/spike and straw yield. Similar findings of significant positive correlation of grain yield with 1000-grain weight, plant height, and grain/spike was reported in earlier studies (Wu et al., 2012; Mandic et al., 2015). Therefore, the selection 
based on these yield traits would providethe future selection and breeding criteria to improve the grain yield in wheat.

\section{Conclusion}

Wheat yield and yield components were significantly improved with the applications of nitrogen and zinc. This study demonstrates that the application of $\mathrm{N}$ (macronutrient) or $\mathrm{Zn}$ (micronutrient) alone may not increase the wheat yield while the high $\mathrm{N}(160 \mathrm{~kg} / \mathrm{ha})$ combined with low $\mathrm{Zn}$ (1 or $2 \mathrm{~kg} / \mathrm{ha}$ ) application is beneficial for enhancing wheat grain yield, $\mathrm{Zn}$ uptake and transport to grain for higher grain yield. It is therefore recommended that nitrogen and zinc could be applied at the rate of 160:2 kg/ha for the optimum yield of wheat crop under prevailing soil and climatic conditions of Bangladesh.

\section{References}

Abbas G, Hassan G, Ali MA, Aslam M, Abbas Z (2010). Response of wheat to different doses of ZnSO4 under Thal desert environment.Pakistan Journal of Botany. 42(6):4079-85.

Abedi T, Alemzadeh A, Kazemeini SA (2011). Wheat yield and grain protein response to nitrogen amount and timing.Australian Journal of Crop Science. 5(3):330.

Aciksoz SB, Yazici A, Ozturk L, Cakmak I (2011). Biofortification of wheat with iron through soil and foliar application of nitrogen and iron fertilizers.Plant and Soil. 349(1-2):215-25.

Adnan M, Shah Z, Ullah H, Khan B, Arshad M, Mian IA, Khan GA, Alam M, Basir A, Ali M, Khan WU (2016). Yield response of wheat to nitrogen and potassium fertilization. Pure and Applied Biology. 5(4):1.

Ahmadi SA, David AA (2016). Effect of Nitrogen and Zinc on yield of wheat (Triticumaestivum L.).International Journal of Multidisciplinary Research Development. 3(2):291-3.

Akram MA, Depar N, Memon MY (2017). Synergistic use of nitrogen and zinc to bio-fortify zinc in wheat grains. Eurasian Journal of Soil Science. 6(4):319-26

Ames NP, Clarke JM, Dexter JE, Woods SM, Selles F, Marchylo B (2003). Effects of nitrogen fertilizer on protein quantity and gluten strength parameters in durum wheat (Triticum turgidum $\mathrm{L}$. var. durum) cultivars of variable gluten strength.Cereal Chemistry. 80(2):203-11.

Barunawati N, HettwerGiehl RF, Bauer B, Von Wirén $N$ (2013). The influence of inorganic nitrogen fertilizer forms on micronutrient retranslocation and accumulation in grains of winter wheat. Frontiers in Plant Science. 2013. 4:320.

BBS (Bangladesh Bureau of statistics), (2002). The Year Book of Agricultural Statistics of Bangladesh, 2001.Statistics and Informatics Division (SID) Ministry of Planning Government of the People's Republic of Bangladesh, Dhaka.

BBS, (Bangladesh Bureau of Statistics), (2017).The Year Book of Agricultural Statistics of Bangladesh, 2016.Statistics and Informatics Division (SID) Ministry of Planning Government of the People's Republic of Bangladesh, Dhaka.

Belete F, Dechassa N, Molla A, Tana T (2018). Effect of nitrogen fertilizer rates on grain yield and nitrogen uptake and use efficiency of bread wheat (Triticum aestivum L.) varieties on the Vertisols of central highlands of Ethiopia. Agriculture and Food Security. 2018. 7(1):78.

Cakmak I (2008). Enrichment of cereal grains with zinc: agronomic or genetic biofortification?.Plant and soil. 2008. 302(1-2):1-7.

Defra, 2019. Farming Statistics Final crop areas, yields, livestock populations and agricultural workforce At June 2018, United Kingdom.

Faizy SE, Mashali SA, Youssef SM, Elmahdy SM (2017). Study of wheat response to nitrogen fertilization, micronutrients and their effects on some soil available macronutrients. Journal of Sustainable Agricultural Sciences, 43(1):55-64.

Firdous S, Agarwal BK, Chhabra V. (2018). Zincfertilization effects on wheat yield and yield 
components. Journal of Pharmacognosy and Phytochemistry. 7(2):3497-9.

Gomez KA, Gomez AA (1984). Statistical Procedures for Agricultural Research.2nd Edn.Jhon Wiley and Sons.New York, Chickester, Brisbane, Toronto, Singapore.P. 680.

Gregorio GB, Senadhira D, Mendoza RD, Manigbas NL, Roxas JP, Guerta CQ (2002). Progress in breeding for salinity tolerance and other abiotic associated stresses in rice.Field Crops Research. 76: 91-101

Gul H, Said A, Saeed B, Ahmad I, Ali K (2011). Response of yield and yield components of wheat towards foliar spray of nitrogen, potassium and zinc.ARPN Journal of Agricultural and Biological Science.6(2).

Imran M, Kanwal S, Hussain S, Aziz T, Maqsood MA (2015). Efficacy of zinc application methods for concentration and estimated bioavailability of zinc in grains of rice grown on a calcareous soil.Pakistan Journal of Agricultural Sciences.52(1).

Keram KS, Sharma BL, Sharma GD, Thakur RKD (2013).Impact of zinc application on its translocation into various plant parts of wheat and its effect on chemical composition and quality of grain.Scientific Research and Essays. 8(45):22182226.

Liu H, Zhao P, Qin S, Nie Z (2018). Chemical fractions and availability of zinc in winter wheat soil in response to nitrogen and zinc combinations. Frontiers in plant science.9:1489.

Majd AN, Fazel M, Lak S (2015).The effect of foliar application of zinc ( $\mathrm{Zn})$ on yield and yield components of irrigated wheat cultivars in Ahvaz weather conditions.International Journal of Bioscience. 2015. 6(3):370-7.
Mandic V, Krnjaja V, Tomic Z, Bijelic Z, Simic A, RuzicMuslic D, Gogic M (2015). Nitrogen fertilizer influence on wheat yield and use efficiency under different environmental conditions. Chilean journal of agricultural research. 75(1):92-7.

Marino S, Tognetti R, Alvino A (2009). Crop yield and grain quality of emmer populations grown in central Italy, as affected by nitrogen fertilization.European Journal of Agronomy. 31(4):233-40.

Nie Z, Zhao P, Wang J, Li J, Liu H (2017). Absorption kinetics and subcellular fractionation of zinc in winter wheat in response to nitrogen supply. Frontiers in plant science. 2017. 8:1435.

Quddus MA, Naser HM, Hossain MA, Hossain MA (2014). Effect of zinc and boron on yield and yield contributing characters of lentil in low ganges river floodplain soil at Madaripur, Bangladesh. Bangladesh Journal of Agricultural Research. 2014. 39(4):591-603.

UNDP and FAO (1988). The experimental site lies at $24.75^{\circ} \mathrm{N}$ latitude and $90.50^{\circ} \mathrm{E}$ longitude. The elevation of the experimental area is $18 \mathrm{~m}$ above the sea level. The experimental land belongs to the "Old Brahmaputra Floodplain" under Agro Ecological Zone-09.

Wang F, Liu X, Shi Z, Tong R, Adams CA, Shi X (2016). Arbuscularmycorrhizae alleviate negative effects of zinc oxide nanoparticle and zinc accumulation in maize plants-a soil microcosm experiment. Chemosphere. 2016. 147:88-97.

Wu X, Chang X, Jing R (2012). Genetic insight into yield-associated traits of wheat grown in multiple rain-fed environments.PloS one. 7(2):e31249. 